\title{
Changing patterns of bacterial substrate decomposition in a eutrophication gradient
}

\author{
H.-G. Hoppe*, H. C. Giesenhagen, K. Gocke \\ Institut für Meereskunde, Düsternbrookerweg 20, D-24105 Kiel, Germany
}

\begin{abstract}
Bacterial variables are expected to respond differently to eutrophication. This was investigated along the eutrophication gradient in the narrow Schlei fjord (northern Germany). Bacterial extracellular enzyme activities (peptidase, $\alpha$ - and $\beta$-glucosidase, chitinase) were measured together with a large number of autotrophic and heterotrophic biological vaniables. Increases of values measured along the eutrophication gradient were generally higher for bacterial substrate uptake and growth than for bacterial counts and enzyme activities. Annual patterns of activities (per volume of water) obtained from stations with different degrees of eutrophication were clearly different from each other. In contrast, annual patterns of activities per bacterial cell at the stations with different degrees of eutrophication were not clearly different from each other, indicating that they did not depend on eutrophication. Size fractionation of enzyme activities revealed that most of the peptidase activity was generally associated with free-living bacteria $(<0.2$ to $3 \mu \mathrm{m}$, average $57 \%$ of total). Chitinase (average $54 \%$ of total) and $\alpha$-/ $\beta$-glucosidases activities during summer were mainly associated with the $>3 \mu \mathrm{m}$ particle size class ( 43 and $52 \%$, respectively). Free enzyme activities $(<0.2 \mu \mathrm{m}$, \% of total) were generally higher in less eutrophic areas than in eutrophic areas. Enzyme activities associated with the bacterial size class were generally higher in eutrophic areas than in less eutrophic areas. It is concluded that particle hydrolysis in eutrophic waters is mainly affected by attached bacterial glucosidic and chitinolytic potentials, while peptides are the preferred substrates of free-living bacteria. To cover bacterial $\mathrm{C}$ demands for growth, exudation by phytoplankton had to be supplemented by bacterial substrate hydrolysis in eutrophic waters, which was, however, not as high as expected.
\end{abstract}

KEY WORDS: Bacterial production Primary production - Extracellular enzyme activity - Exudation . Substrate decomposition - Eutrophication gradient

\section{INTRODUCTION}

Biological consequences of eutrophication depend on the geographic, hydrographic and climatic situation of a water body and also on the type of eutrophication. Nevertheless, there are some commonly observed and well-documented changes in the balance between autotrophic and heterotrophic processes which are combined with a high degree of eutrophication: Photosynthetic plankton is frequently dominated by cyanobacteria. The contribution of the microbial loop organisms in recycling processes is generally smaller than in oligotrophic waters (Bird \& Kalff 1984). Absolute values of bacterial substrate uptake and growth are high,

•E-mail: hhoppe@ifm.uni-kiel.de but the contribution of heterotrophic biomass and biomass production to the total standing stock and production is relatively low (Schiewer \& Gocke 1995).

In contrast to this general knowledge, relatively little is known about the reasons for the different response of bacteria to eutrophication. Information about the initial processes of the microbial loop and their modification by eutrophication could probably provide a key for a better understanding of the function of bacteria in eutrophic waters. In detail, the question is: Which of the diverse factors of bacterial substrate conditioning, substrate uptake and growth are most strongly influenced (favoured or repressed) by eutrophication? This could help to explain the generally reduced role of bacterial heterotrophism under eutrophic and hypertrophic conditions. 


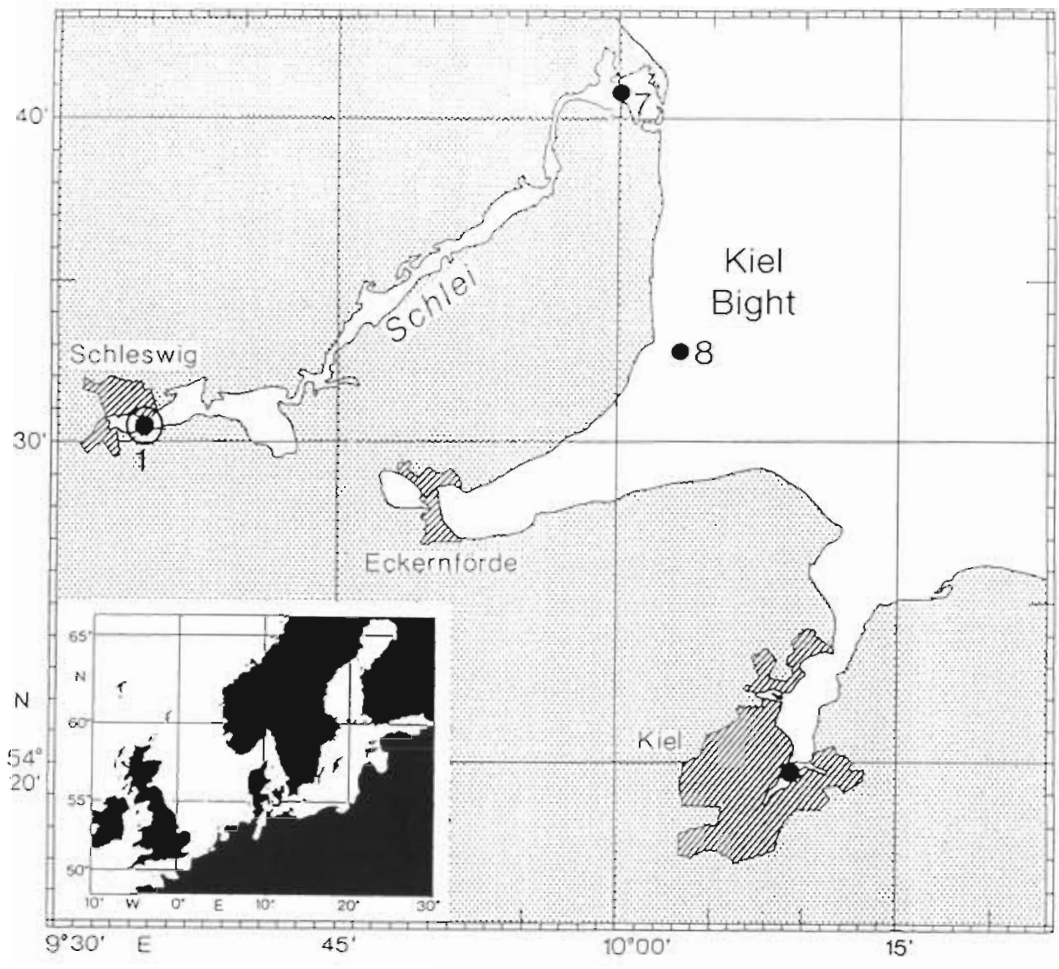

Fig. I Map showing the situation of the sampling stations Stn 1 (inner Schlel, hypertrophic), Stn 7 (Schleimunde, eutrophic) and the mesotrophic reference Stn 8 in the Kiel Bight

We investigated the narrow Schle fjord (Germany) along its eutrophication gradient from the hypertrophic innermost part to the eutrophic outer part, and additionally a reference station in the adjacent Baltıc Sea. The activity of different extracellular enzymes was estımated together with a large number of other biological and chemical variables. Relationships between enzyme activities and variables of bactenal growth and substrate uptake as well as primary production were compared on selected stations along the eutrophication gradient and the reference station. In addition, particle size fractionation of the water provided information about the preferred sites of bacterial substrate hydrol sis and the changes which this pattern undergoes along the eutrophication gradient. Finally, changes of the relative importance of enzymatic substrate hydrolysis for bacterial $\mathrm{C}$ demand in waters with different degrees of eutrophication are discussed.

\section{MATERIALS AND METHODS}

Study site. The Schlel fjord is situated on the peninsula of Schleswig-Holstein, about haltway between Hamburg and the Danısh border. The fjord extends from southwest to northeast over 40 $\mathrm{km}$ with widths varying between 50 and $2000 \mathrm{~m}$. The average depth is about $2 \mathrm{~m}$ (up to $8 \mathrm{~m}$ in the navigation channel) and the connection with the open sea is established by a narrow opening of $95 \mathrm{~m}$ width. Due to its durection the fjord is directly exposed to the prevailing westerly winds which occasionally cause a water exchange, at least in its middle and outer parts. The fjord is mostly stratified, but its bottom water is also always oxic. The fjord is heavily eutrophied by terrestrial runoff from its rural surroundings and by the (purified) sewage of adjacent villages. There is a heavy mud layer on the bottom which counteracts recent efforts to umprove water quality. During the summer period the phototrophic community is dominated by Chlorella $\mathrm{sp}$. and the coccoid and aggregate-forming cyanobacterium Microcystis aeruginosa (Rieper 1976).

Seven sampling stations $(1$ to 7 ) were located in the fjord and 1 reference station (8) outside in the Kiel Bight, which is $28 \mathrm{~m}$ deep and less eutrophic (Fig. 1). In this paper we present only results obtained from the 3 main stations: 1 (hypertrophic innermost part) 7 (mouth of Schlei fjord, water mixing area) and 8 (reference station).

Methods. Monthly investigations were performed on board the small research ship 'Littorina' over a period of 27 mo from January 1991 to March 1993. On a few occasions the ship could not go into the fjord or only into its outer part because of low water level or ice cover. Water samples were taken at $1 \mathrm{~m}$ depth by a Niskin sampler.

Temperature and salinity were determined by a TS probe (WTW, Wellheim, Germany). Inorganic nutrients (ammonia, nitrite, nitrate, phosphate, dissolved inorganıc carbon) were determined according to standard procedures (Grasshoff et al, 1983).

Chlorophyll a was measured by the colorimetric method according to Lorenzen (1967), using 96\% ethanol for extraction.

Primary production was measured by ${ }^{14} \mathrm{C}$-bicarbonate uptake of the planktonic algae and cyanobacteria. Duplicates were incubated at simulated in situ light conditions adjusted to $100,65,27,7$ and $2.5 \%$ of incident light intensity by neutral light filters. Incubation was from sunnse to noon. Labelled particles were harvested on Sartorus membrane filters of $0.2 \mu \mathrm{m}$ pore 
size. Filters were placed into picovials (Beckmann) filled with $5 \mathrm{ml}$ of scintillation cocktail (Lumagel) and measured in a Beckman scintillation counter (the latter procedure is valid for all the following radioactive tracer applications). Exudates of phytoplankton were determined in $0.2 \mu \mathrm{m}$ filtrates of ${ }^{14} \mathrm{C}$-bicarbonate supplemented subsamples after acidification $\left({ }^{14} \mathrm{CO}_{2}\right.$ was expelled over night) and calculated as \% of primary production.

Bacterial total counts (total bacterial numbers, TBN) and cell sizes were determined by acridine orange staining and epifluorescence microscopy according to Hobbie et al. (1977) using polycarbonate membranes (0.2 $\mathrm{\mu m}$ pore size) for filtration and a New Porton Grid in the eyepiece. Bacteria in 20 fields or a total of 200 bacteria were counted per sample and the sizes of at least 50 bacteria were measured for the calculation of bacterial cell volumes. Colony-forming bacteria (colony-forming units, CFU) were determined on ZoBell agar 2116 e (ZoBell 1946) adjusted to salinities of 0,8 and 23 , for detection of freshwater bacteria, brackish water bacteria and marine bacteria tolerating brackish water. Coliforms were selected on Endo nutrient pads (Gocke \& Rheinheimer 1991).

Bacterial growth and biomass production were determined by ${ }^{3} \mathrm{H}$-thymidine and ${ }^{3} \mathrm{H}$-leucine uptake according to Fuhrman \& Azam (1982) and Simon \& Azam (1989), respectively. Uptake was saturated at $13.5 \mathrm{nmol} \mathrm{l}^{-1}$ for thymidine and $107 \mathrm{nmol} \mathrm{l}^{-1}$ for leucine. Conversion factors applied were $1.1 \times 10^{6} \mathrm{cells}_{\mathrm{pmol}}^{-1}$ incorporated thymidine (Riemann et al. 1987) and $0.25 \times 10^{-6} \mu \mathrm{g} \mathrm{C} \mu \mathrm{m}^{-3}$ bacterial volume (derived from Simon \& Azam 1989). Triplicates were incubated at in situ temperature for 20 min to $1 \mathrm{~h}$, which was in the linear phase of substrate uptake, and filtered on $0.2 \mu \mathrm{m}$ pore size polycarbonate membranes (Costar). Maximal substrate uptake $\left(V_{m}\right)$ of glucose and turnover rates $\left(T_{r}\right)$ of glucose, acetate and leucine were determined in triplicates according to Gocke (1977) at substrate

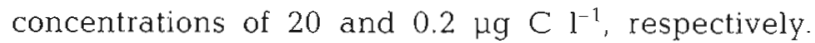
Labelled particles were harvested on $0.2 \mu \mathrm{m}$ pore size cellulose-acetate membranes (Sartorius).

Community respiration was determined by the oxygen demand over $24 \mathrm{~h}$ at in situ temperature. Oxygen was measured by the Winkler method.

Extracellular enzymes activities (EEA) were determined in principle according to Hoppe (1993). Measured enzyme activities were aminopeptidases (by using the model substrate leucine-methylcoumarinylamide $=$ leu-MCA) $\alpha$ - and $\beta$-glucosidases (by the model substrates methylumbelliferyl- $\alpha$ or $\beta$-glucopyranoside $=$ MUF- $\alpha$ or $\beta$-glucoside) and chitinase (by methylumbelliferyl-N-acetylglucosaminide $=$ MUFglucosaminide). Fluorogenic chemicals were from Sigma-Aldrich Chemie, Dreisenhofen, Germany. Max- imal velocities of hydrolysis $\left(H_{\mathrm{m}}\right)$ and hydrolysis rates $\left(H_{1}\right)$ were determined by enzyme kinetics using 6 substrate concentrations from 0.1 up to $1 \mathrm{mM}$ in the first experiments. After having determined the enzyme kinetics the experiments were continued with the 'one concentration' method, generally using $0.1 \mu \mathrm{M}$ of substrate for the estimation of $H_{r}$ and $500 \mu \mathrm{m}$ or $1 \mathrm{mM}$ for the estimation of $H_{\mathrm{m}}$ at Stns $7 / 8$ or 1 , respectively. Incubations of 2 to $6 \mathrm{~h}$ at in situ temperature were in the linear phase. Triplicates of unfractionated samples and fractionations of samples by 0.2 and $3 \mu \mathrm{m}$ polycarbonate filters were used to calculate the total enzyme activity, the activity of dissolved enzymes $(<0.2 \mu \mathrm{m})$, the enzyme activity of free-living bacteria $(>0.2$ to $<3 \mu \mathrm{m})$ and the enzyme activity of attached bacteria $(>3 \mu \mathrm{m})$. Fluorescence was read in a spectrofluorometer (Kontron SFM 25), excitation $364 \mathrm{~nm}$ and emission $445 \mathrm{~nm}$, in $1 \mathrm{~cm}$ plastic cuvettes. For the calculation of enzyme activity (in terms of carbon hydrolysed from the model substrate per litre and hour) calibration factors were used, which were obtained from fluorescence readings of low methylumbelliferon (MUF) and methylcoumarinyl-amide (MCA) concentrations dissolved in seawater. Calibration factors considered the organic carbon content of model substrates and the fluorescence per unit of the fluorescent tracer.

Statistics. Data of all variables were tested by nonparametric statistics. A matrix of correlation between annual cycles of variables was established by using multiple linear regression (MLR) statistics (Statistica). Selected results of the correlation matrix are presented. Correlation of annual patterns of specific enzyme activities per bacterial cell were tested by Mann-Whitney rank sum test and Wilcox signed rank tests.

\section{RESULTS}

\section{Salinity and temperature}

Salinity ranged from 13 to 20 at $\operatorname{Stn} 8$ (reference station) and from 5 to 8 at Stn 1 (inner Schlei) (Table 1). Temperature ranged from 0 to $22^{\circ} \mathrm{C}$. Maximal summer temperature was lower in the first year of investigation than in the second (Fig. 3d).

\section{Nutrients}

The high level of eutrophication of the Schlei is documented by the concentrations of nutrients. These ranged for nitrate at Stn 1 from 0.01 to $258 \mu \mathrm{M}$, at $\operatorname{Stn} 7$ from 0.4 to $105 \mu \mathrm{M}$ and at the reference Stn 8 from 0 to $13 \mu \mathrm{M}$. The corresponding ranges of ammonia were 

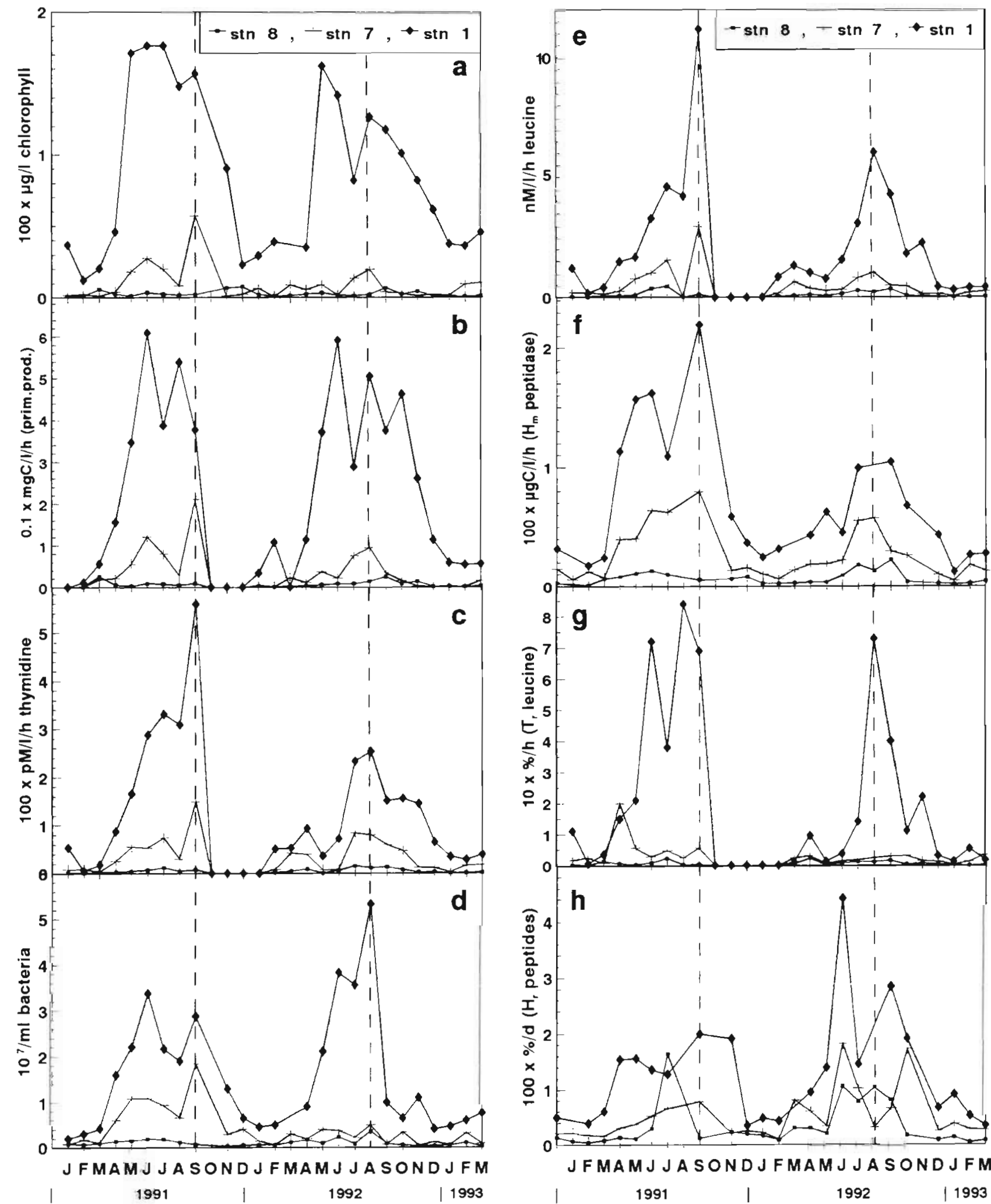

Fig. 2. Annual cycles of selected variables at Stns 1, 7 and 8. (a) Chlorophyll a, (b) primary production, (c) thymidine uptake, (d) total bacterial counts, (e) leucine uptake, (f) $H_{m}$ peptidase, (g) $T_{\mathrm{r}}$ leucine, (h) $H_{\mathrm{r}}$ peptides. Vertical dashed lines: annual temperature peaks 
0.6 to $43(\operatorname{Stn} 1), 0.5$ to $13(\operatorname{Stn} 7)$ and 0.4 to $6(\operatorname{Stn} 8)$. The corresponding ranges for phosphate were 1 to 14 (Stn 1), 0.2 to 4 (Stn 7) and 0.1 to 3 (Stn 8) (Table 1). Nutrients in the inner Schlei did not completely

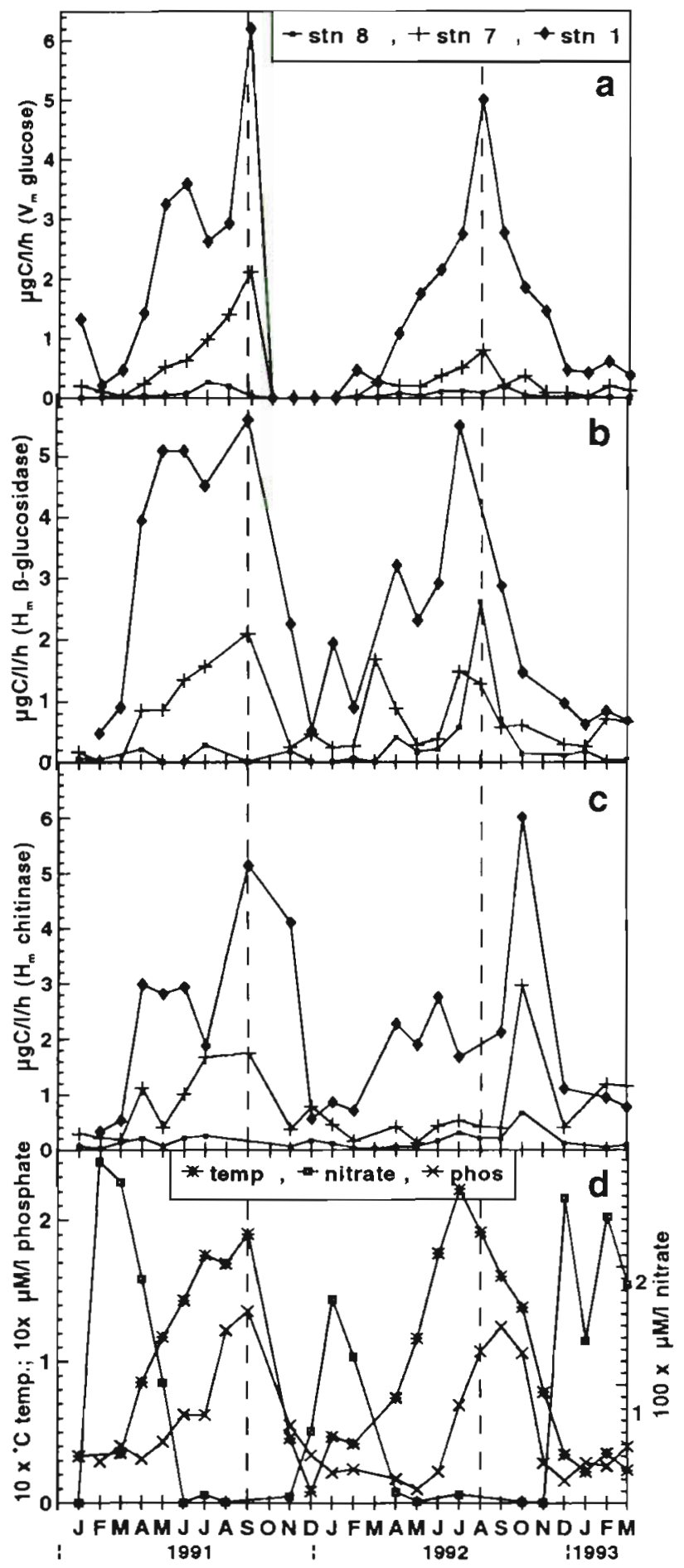

deplete during the growth period. High phosphate concentrations in late summer were caused by anoxic conditions in the sediment and near bottom layer of water (Fig. 3d) (Gocke \& Rheinheimer 1995).

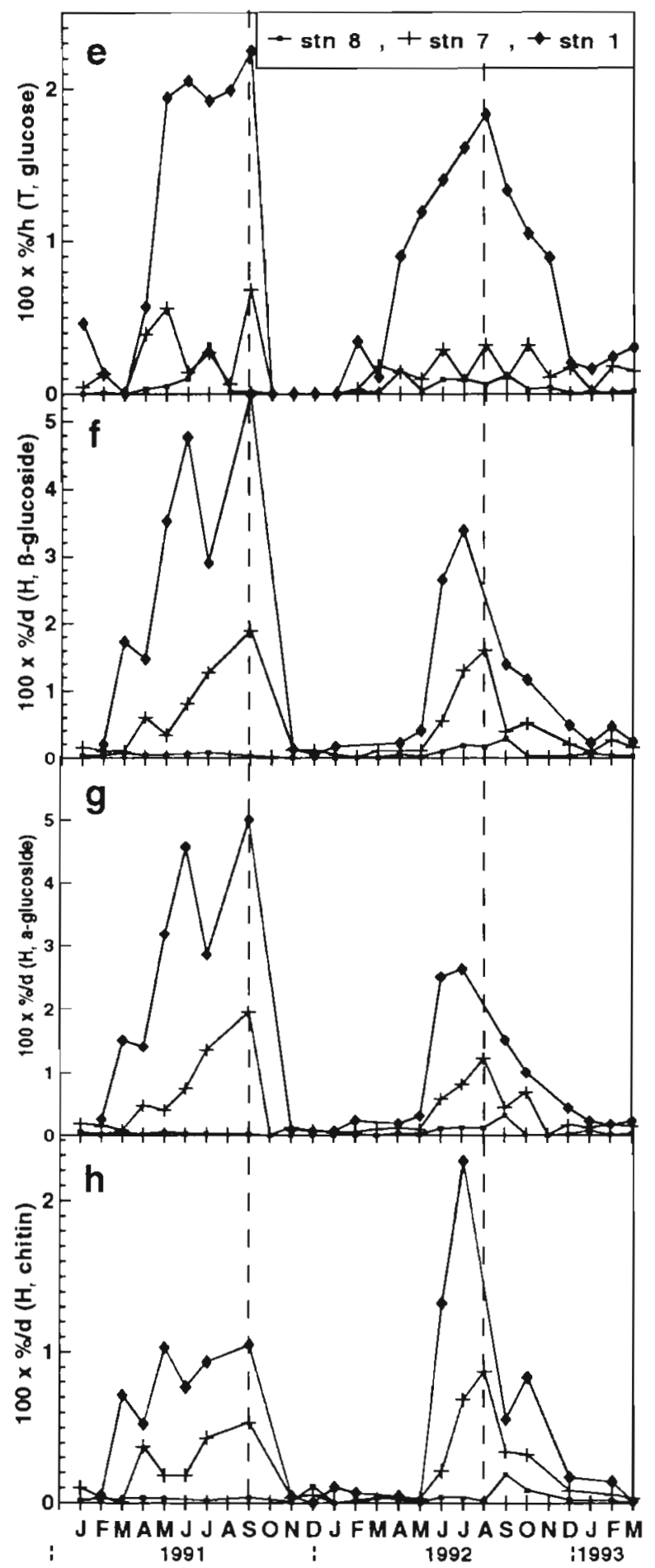

Fig. 3. Annual cycles of selected variables at Stns 1,7 and 8. (a) $V_{\mathrm{m}}$ glucose uptake, (b) $H_{\mathrm{m}} \beta$-glucosidase, (c) $H_{\mathrm{m}}$ chitinase. (d) Different variables, only at Stn 1 . temperature, nitrate, phosphate. (e) $T_{\mathrm{r}}$ glucose, (f) $H_{\mathrm{r}} \beta$-glucoside, (g) $H_{\mathrm{r}} \alpha$-glucoside, (h) $H_{\mathrm{r}}$ chitin. Vertical dashed lines: annual temperature peaks 


\section{Annual cycles of phytoplanktonic, bacterial and enzymatic variables}

All presented variables showed a strong decrease from the inner fjord (Stn 1) to the mouth of the fjord (Stn 7) and the reference station in the Kiel Bight (Stn 8), especially during the growth seasons (Figs. 2 \& 3). Maxima of activities coincided in most cases with the peaks of temperature. Especially at Stn 1 during spring, chlorophyll a and primary production increased first, followed by enzyme activities, substrate uptake and finally by bacterial growth (Figs, 2a, b, c, e, f, $g \& 3 a, b)$. All enzyme activities correlated with each other at Stns 1 and 7 (mostly at $p<0.01$, according to MLR statistics) with the exception of $H_{\mathrm{m}}$ of chitinase which did not correlate with $H_{r}$ of $\alpha$-glucosides, $H_{r}$ of $\beta$-glucosides and $H_{\mathrm{r}}$ of chitin.

\section{Annual cycles of cell-specific enzyme activities}

In contrast to community enzyme activities, cellspecific enzyme activities (specific $H_{\mathrm{m}}$ and $H_{\mathrm{r}}$ ) at the 3 stations with different degrees of eutrophication were not clearly separated from each other according to statistical Mann-Whitney and Wilcox tests (Fig. 4). The tests were run without some exceptionally high values at Stns 7 and 8 , the justification for this is presented in the 'Discussion' In detail there were some differences between the annual patterns of the different specific enzyme activities at the hypertrophic Stn 1. Specific $H_{\mathrm{m}}$ of peptidase and $\alpha$-glucosidase did not vary significantly over the year and slightly increased in spring and fall. $H_{\mathrm{m}}$ of $\beta$-glucosidase showed an irregular pattern, with highest values during winter Chitinase activity was low in summer and increased during late fall. $H_{\mathrm{r}}$ of peptides was rather similar over the year, with a small decrease in summer and an increase in late fall. $H_{\mathrm{r}}$ of $\alpha$-and $\beta$-glucosides and chitins showed an increase from spring to fall and a decrease in winter. Annual mean values of variables were higher at Stns 7 and 8 than at Stn 1 . This resulted mainly from some exceptionally high values at Stns 7 and 8 .

\section{Relations of variables between hypertrophic and reference areas}

Annual mean values and ranges of selected variables are shown in Table 1. Ranges were in most cases widest at $\operatorname{Stn} 7$ (Schleimünde), because this area is alternatingly influenced by marine and fjord conditions. Exudates as \% of primary production were surprisingly low at Stn 1 (inner Schlei) (Gocke \& Rheinheimer 1995). Escherichia coli numbers can be very high (and above European limits for bathing water

Table 1. Annual mean values from April 1992 to March $1993(n=12)$ and ranges of variables (in parentheses) in the Kiel Bight (Stn 8), at the mouth of the Schlei fjord (Schleimünde, Stn 7) and in the hypertrophic inner Schlei (Stn 1)

\begin{tabular}{|c|c|c|c|}
\hline Parameter & Kiel Bight & Schleimünde & Inner Schlei \\
\hline Salinity (S) & $17.5(13.1-19.8)$ & $15.6(12.1-18.9)$ & $6.5(5.1-7.6)$ \\
\hline Ammonia $(\mu \mathrm{M})$ & $1.64(0.4-6.3)$ & $4.35(0.5-12.6)$ & $11.78(0.6-43.1)$ \\
\hline Nitrate $(\mu \mathrm{M})$ & $3.02(0-12.95)$ & $17.3(0.37-105.4)$ & $70.02(0-258)$ \\
\hline Phosphate $(\mu \mathrm{M})$ & $1.01(0.07-3.03)$ & $1.77(0.16-3.71)$ & $4.93(0.93-13.6)$ \\
\hline Secchi depth (m) & $6.53(4.0-11.0)$ & $2.78(1.0-5.0)$ & $0.71(0.4-2.3)$ \\
\hline Chlorophyll a $\left(\mathrm{Hg} \mathrm{l}^{-1}\right)$ & $2.42(0.8-6.9)$ & $6.74(1.3-19.6)$ & $85.66(35.1-162)$ \\
\hline Primary production $\left(\mathrm{mg} \mathrm{C}^{-1} \mathrm{~h}^{-1}\right)$ & $0.01(0-0.03)$ & $0.03(0-0.1)$ & $0.27(0.05-0.59)$ \\
\hline Exudates ( $\%$ primary production) & $13.8^{a}(2-31.7)$ & $4.39(1.2-16.2)$ & $1.02(0.2-3)$ \\
\hline Respiration ( $\mathrm{mg} \mathrm{O}_{2} \mathrm{l}^{-1} \mathrm{~d}^{-1}$ ) & $0.25(0-0.51)$ & $0.35(0.04-0.64)$ & $0.95(0.18-2.06)$ \\
\hline Total bacteria $\left(10^{6} \mathrm{ml}\right\}$ & $1.13(0.3-3.6)$ & $2.28(0.5-5)$ & $17.28(4.1-53.2)$ \\
\hline E. coli (colonies $/ 100 \mathrm{ml}$ ) & $8.92(0-63)$ & $437.6(0-5000)$ & $1475(0-8775)$ \\
\hline${ }^{3} \mathrm{H}$-Thymidine-incorporation $\left(\mathrm{pM}^{-1} \mathrm{~h}^{-1}\right)$ & $6.17(0.89-15.6)$ & $32.27(2.5-84.2)$ & $108.9(28.3-253)$ \\
\hline${ }^{3} \mathrm{H}$-Leucine-incorporation $\left(\rho \mathrm{M} \mathrm{I}^{-1} \mathrm{~h}^{-1}\right)$ & $111.4(11-337)$ & $377(50-1030)$ & $1869(305-6050)$ \\
\hline$V_{\mathrm{m}}$ glucose $\left(\mathrm{ng} \mathrm{C \textrm {I } ^ { - 1 } \mathrm { h } ^ { - 1 } )}\right.$ & $56.9(9-183)$ & $261.8(20-794)$ & $1716(369-5000)$ \\
\hline$T_{r}$ glucose $\left(\% \mathrm{~h}^{-1}\right)$ & $5.47(0.6-15)$ & $16.5(1.7-32)$ & $92.5(16-183)$ \\
\hline$H_{\mathrm{m}}$ peptidase $^{\mathrm{b}}\left(\mu \mathrm{g} \mathrm{Cl}^{-1} \mathrm{~h}^{-1}\right)$ & $7.16(1.62-22)$ & $24.05(4.5-57)$ & $57.3(12-1.04 .4)$ \\
\hline$H_{r}$ peptides $\left(\% \mathrm{~d}^{-1}\right)$ & $40.2(3.6-105)$ & $72.1(24.8-182)$ & $157.3(34.8-442)$ \\
\hline$H_{\mathrm{m}} \alpha$-glucosidase $\left(\mu \mathrm{gCl}^{-1} \mathrm{~h}^{-1}\right)$ & $0.39(0-1.79)$ & $0.38(0.14-1.3)$ & $1.61(0.4-4.8)$ \\
\hline$H_{\mathrm{r}} \alpha$-glucosides $\left(\% \mathrm{~d}^{-1}\right)$ & $7.2(0.9-31.2)$ & $41.2(9.6-121.2)$ & $100.9(18.4-262)$ \\
\hline 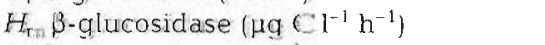 & $0.44(0-2.62)$ & $0.65(0.3-1.5)$ & $2.32(1.5-5.5)$ \\
\hline$H_{\mathrm{r}} \beta$-glucosides $\left(\% \mathrm{~d}^{-1}\right)$ & $7.8(1.1-28)$ & $46.7(7.8-161.1)$ & $114.7(20.9-338)$ \\
\hline
\end{tabular}



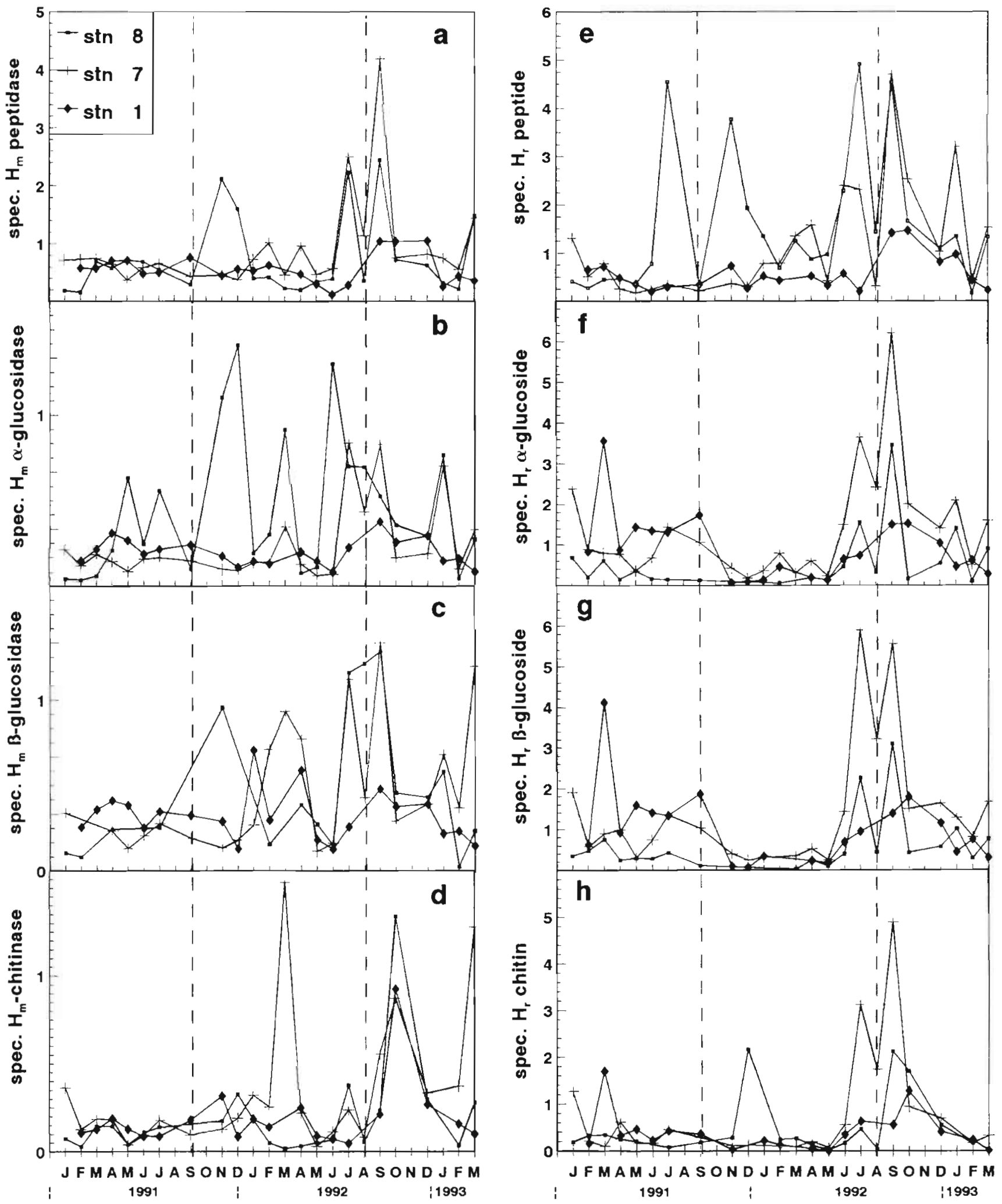

Fig. 4. Annual cycles of selected specific enzyme activities $\left(H_{\mathrm{m}}\right.$ or $H_{\mathrm{r}}$ per bacterial cell) at Stns 1, 7 and 8. (a) $H_{\mathrm{m}}$ peptidase, (b) $H_{\mathrm{m}}$ $\alpha$-glucosidase, (c) $H_{\mathrm{m}} \beta$-glucosidase, (d) $H_{\mathrm{m}}$ chitinase, (e) $H_{\mathrm{r}}$ peptides, (f) $H_{\mathrm{r}} \alpha$-glucosides, (g) $H_{\mathrm{r}} \beta$-glucosides, (h) $H_{\mathrm{r}}$ chitin. Units: (a) $10 \mathrm{fgCh} \mathrm{C}^{-1}$, (b to d) fg $\mathrm{Ch}^{-1}$, (e to h) $\% \mathrm{~d}^{-1} \times 10^{-5}$ 


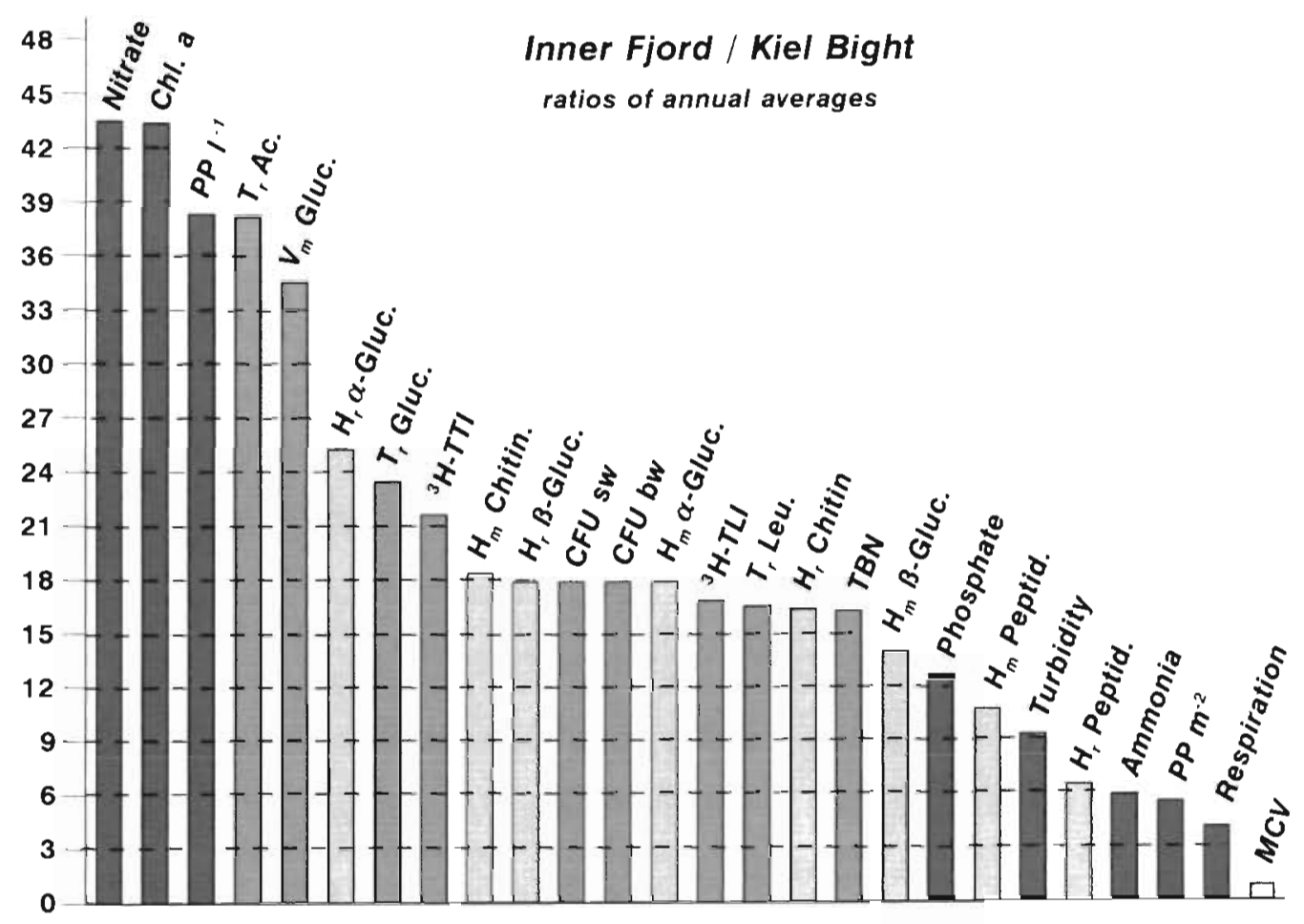

Fig. 5. Ratios between annual averages (from April 1992 to March 1993, except August and November) of selected variables at the hypertrophic station in the inner Schlei (Stn 1) and the reference station in the Kiel Bight (Stn 8), calculated from the averages of the ratios of the monthly observations at the 2 stations.

Chl, $a=$ chlorophyll $a$

$P P l^{-1}=$ primary production $l^{-1}$

$T_{\mathrm{r}}$ Ac. $=$ turnover rate of acetate

$V_{\mathrm{m}}$ Gluc. = maximal velocity of glucose uptake

$H_{r} \alpha$-Gluc. $=$ hydrolysis rate of $\alpha$-glucosides

$T_{\mathrm{r}}$ Gluc. = turnover rate of glucose

${ }^{3} \mathrm{H}-\mathrm{TTI}=$ tritiated thymidine incorporation

$H_{\mathrm{m}}$ Chitin. = maximal velocity of hydrolysis by chitinases

$H_{\mathrm{r}} \beta$-Gluc. $=$ hydrolysis rate of $\beta$-glucosides

CFU sw = colony-forming units of marine bacteria

CFU bw = colony-forming units of brackish water bacteria

quality) in the entire Schlei (Strns 1 and 7). Many variables showed a steep step from the mouth of the fjord (Stn 7) to the coastal water (Stn 8, Kiel Bight), with the exception of chlorophyll, primary production, respiration, total bacteria numbers, and the maximal hydrolysis rates of $\alpha$-and $\beta$-glucosides.

Fig. 5 summarises the ratios of annual average values of variables (obtained from the averages of the ratios of the monthly observations in 1992/93) at the most eutrophic Stn 1 (inner Schlei) and the reference Stn 8 (Kiel Bight). It has to be kept in mind that averages were calculated from measurements of variables per volume of surface water. Only primary production $(\mathrm{PP})$ is presented per volume ( $\mathrm{PP}^{-1}$ ) and also integrated over depth ( $\left.\mathrm{PP} \mathrm{m}^{-2}\right)$. In the latter case it becomes clearly visible that primary production is limited by turbidity in the inner Schlei. Most ratios of enzyme
$H_{\mathrm{m}} \alpha-$ Gluc $=$ maximal velocity of hydrolysis by $\alpha$-glucosidases

${ }^{3} \mathrm{H}-\mathrm{TLI}=$ tritiated leucine incorporation

$T_{\mathrm{r}}$ Leu. = turnover rate of leucine

$H_{\mathrm{I}}$ Chitin = hydrolysis rate of chitin

$\mathrm{TBN}=$ total bacterial numbers

$H_{\mathrm{m}} \beta$-Gluc. $=$ maximal velocity of hydrolysis by $\beta$-glucosidases $H_{\mathrm{m}}$ Peptid. = maximal velocity of hydrolysis by peptidases Turbidity = Secchi depth

$H_{I}$ Peptid. = hydrolysis rate of peptides

$\mathrm{PP} \mathrm{m}^{-2}=$ primary production $\mathrm{m}^{-2}$

$\mathrm{MCV}=$ mean cell volume of bacteria

activities were similar or lower than those of bacterial total counts (TBN), substrate uptake and growth (tritiated thymidine incorporation, ${ }^{3} \mathrm{H}$-TTI) and these were again lower than those of phytoplanktonic variables (chl a, $\mathrm{PP} \mathrm{I}^{-1}$ ). If the data set of 1991/92 (which was less complete) was used for the calculation of the ratios of annual mean values at the 2 stations, their sequence changed in comparison to the sequence in 1992/93. This was generally attributed to the different weather conditions during the 2 years of investigation.

\section{Particle associated and free bacterial enzyme activities}

Hypertrophic waters are characterised by high loads of living and detrital particles during the growth 
season which are more or less colonised by bacteria. One can expect this to be reflected by the spatial and temporal distribution of measured extracellular enzyme activities. $H_{\mathrm{m}}$ of protease of attached bacteria (>3 $\mu \mathrm{m}, \%$ of total activity) increased together with the particle content of the water during the growth season in the eutrophic part of the fjord, but it was relatively low in comparison to the other enzymes (Table 2). $H_{\mathrm{m}}$ of free bacteria (size class $>0.2$ to $<3 \mu \mathrm{m}$ ) contributed mostly the largest fraction of total protease activity, especially during the cold season; it had an average of $66 \%$ of total activity at Stn 1 and a tendency for decrease at Stns 7 and 8 (63.5 and 40.4\% of total activity, respectively). $H_{\mathrm{m}}$ of protease in the dissolved fraction $(<2 \mu \mathrm{m})$ showed very little activity at Stn 1 (inner Schlei, average 10.8\% of total activity) with a strong tendency for increase in the outer less eutrophic stations ( 7 and 8) especially during the cold season (Table 2 ). $H_{\mathrm{r}}$ of protein showed in principle the same seasonal patterns as $H_{\mathrm{m}}$, but averages of $H_{\mathrm{r}}$ were relatively lower for the free bacteria fraction and equal or higher for free enzymes and attached bacteria (not included in the table because the data set was not complete).

Patterns of particle size fractionation of chitinase $\left(H_{\mathrm{m}}\right)$ differed strongly from those of protease. The most obvious phenomenon was that $H_{\mathrm{m}}$ values of free dissolved enzymes (during the cold season) and of enzymes associated with the $>3 \mu \mathrm{m}$ particles (during the growth season) contributed relatively large por-

Table 2. Contributions (\%) of particle size classes to total enzyme activities $(100 \%)$ at the hypertrophic Stn 1, the eutrophic $\operatorname{Stn} 7$, and the less eutrophic reference $\operatorname{Stn} 8$. $H_{\mathrm{m}}$ : maximal velocity of hydrolysis. For values in parentheses the data set was not complete

\begin{tabular}{|lrrrrrrr}
\hline & \multicolumn{2}{c}{$\begin{array}{c}\text { Growth season } \\
\text { (Apr-Sep) }\end{array}$} & \multicolumn{3}{c}{$\begin{array}{c}\text { Cold season } \\
\text { (Oct-Mar) }\end{array}$} \\
\multicolumn{1}{c}{ Stn: } & 1 & 7 & 8 & 1 & 7 & 8 \\
\hline$H_{\mathrm{m}, \text { protease }}$ & & & & & & \\
$>3 \mu \mathrm{m}$ & 37.3 & 26.3 & 17.5 & 9.1 & 10.5 & 24.8 \\
$>0.2$ to $<3 \mu \mathrm{m}$ & 54.5 & 63.6 & 45.7 & 77.7 & 63.4 & 35.1 \\
$<0.2 \mu \mathrm{m}$ & 8.3 & 10.1 & 36.6 & 13.2 & 26.1 & 40.1 \\
$H_{\mathrm{m}}, \alpha$-glucosidase & & & & & & \\
$>3 \mu \mathrm{m}$ & 43.2 & 24.4 & 44.7 & 15.3 & 31.1 & 28.5 \\
$>0.2$ to $<3 \mu \mathrm{m}$ & 45.5 & 56.9 & 17.5 & 58.6 & 26.9 & $(15.5)$ \\
$<0.2 \mu \mathrm{m}$ & 10.9 & 18.8 & 37.8 & 25.9 & 41.9 & 55.9 \\
$H_{\mathrm{m}}, \beta$-glucosidase & & & & & & \\
$>3 \mu \mathrm{m}$ & 52.1 & 37.9 & - & 25.1 & 20.5 & - \\
$>0.2$ to $<3 \mu \mathrm{m}$ & 42.9 & 54.3 & - & 54.2 & 46.2 & - \\
$<0.2 \mu \mathrm{m}$ & 5.0 & 7.8 & - & 20.7 & 33.3 & - \\
$H_{\mathrm{m}}$, chitinase & & & & & & \\
$>3 \mu \mathrm{m}$ & 53.8 & 42.9 & 40.9 & 16.2 & $(30.1)$ & $(35.2)$ \\
$>0.2$ to $<3 \mu \mathrm{m}$ & 36.5 & 29.0 & 25.4 & 41.7 & 18.8 & 19.6 \\
$<0.2 \mu \mathrm{m}$ & 9.6 & 28.1 & 33.8 & 42.2 & 51.1 & 45.2 \\
& & & & & & \\
\hline
\end{tabular}

tions of total activity at the expense of the free bacterial enzymes (Table 2). Values of chitin turnover $\left(H_{r}\right.$, not shown) demonstrated even more clearly that chitin degradation via hydrolysis is mainly a function of attached and dissolved enzymes and that the contribution of free bacteria is even lower than suggested by chitinase potential $\left(H_{\mathrm{m}}\right)$.

Patterns of potentials $\left(H_{\mathrm{m}}\right)$ of extracellular $\alpha$ - and $\beta$-glucosidases were in a way intermediate between those of protease and chitinase (Table 2). Especially $\beta$-glucosidase was to a high degree associated with attached bacteria, also during winter. $\alpha$-Glucosidase resembled more the patterns of chitinase with respect to changes between Stns 1 (inner Schlei) and 8 (Kiel Bight). In the latter the free bacteria fraction frequently (especially during the growth season) contributed very little to the total activity. While the percentage of attached bacterial activity was similar to or slightly higher than at Stn 1, dissolved enzyme activity showed a relatively strong increase.

\section{DISCUSSION}

The aim of this study was to specify the effects of hypertrophication on bacterial extracellular enzyme activities and to range these activities in a scale together with other variables of organic matter decomposition. Enzymatic hydrolysis makes the pool of polymeric substances accessible for bacterial nutrition by adding substrates to the (small) pool of monomeric substances which can be directly used by bacteria. Hypertrophication can affect bacterial processes like hydrolysis and uptake of substrates as well as growth and respiration and their coupling to photoautotrophic processes in different ways, but this can only be recognised in comparison to the conditions in a less eutrophic reference area. We are aware of the fact that land-derived inputs of organic matter and varying salinities could interfere with our attempt to attribute the measured changes of variables to the different degrees of eutrophication. However, hypertrophic conditions are nearly always combined with these factors and thus it is not worthwhile trying to differentiate between them. Furthermore, land-derived inputs of organic matter into the hypertrophic part of the fjord are certainly small in comparison to its enormously high primary production.

In the inner Schlei (Stn 1) primary production and bacterial production differed by a factor of 62 , while in the reference station in the Kiel Bight (Stn 8) this factor was only 40. Standing stocks of phytoplankton and bacterioplankton differed by a factor of 5 at Stn 1 and by 2.1 at Stn 8 . These data suggest that the microbial pathway of substrate decomposition was generally less 
pronounced in the hypertrophic than in the oligotrophic waters under observation. The relatively low standing stock of bacteria in comparison to phytoplankton in eutrophic water was not compensated by relatively higher bacterial secondary production in comparison to primary production, as was suggested by Bird \& Kalff (1984).

Absolute values of enzyme activities in the hypertrophic Stn 1 ranged from 176 to $3041 \mathrm{nmol} \mathrm{l}^{-1} \mathrm{~h}^{-1}$ for peptidase, from 22.4 to 66.7 for $\alpha$-glucosidase, from 32.2 to 76.4 for $\beta$-glucosidase and from 4.4 to 83.3 for chitinase during the $2 \mathrm{yr}$ of observation. These values are higher than those reported from other eutrophic sea and freshwater environments, summarised by Vrba et al. (1992), with the exception of a few (extreme) environments, e.g. eutrophic billabongs (Boon 1990), ponds (Somville 1984) and a tropical lagoon (Hoppe et al. 1983).

The subsequent discussion on the extracellular enzymes and their relations to other variables is based on the following observations:

(1) Enzyme activities of bacterial substrate decomposition were generally less enhanced by hypertrophic conditions than variables of phytoplankton, bacterial substrate uptake and bacterial growth (Table 1, Fig. 5).

(2) Annual cycles of all enzyme variables correlated excellently with other bacterial stock and activity parameters and with phytoplankton variables in the hypertrophic area, while in the reference station this was mainly only valid for protease activities (Figs. 2 \& 3).

(3) Annual patterns of enzyme activities obtained from stations with different degrees of eutrophication were clearly separated from each other. Annual patterns of cell-specific enzyme activities at these stations were not clearly separated from each other (Figs. 2 to 4$)$.

(4) Size fractionation of particles in the water revealed that proteins were predominantly hydrolysed by free-living bacteria, while chitinolytic activity was mainly due to attached bacteria and free dissolved enzymes. The same tendency as for chitinase was observed for $\alpha$-and $\beta$-glucosidases (Table 2 ).

\section{Relative changes of variables in gradients of eutrophication}

The relative changes of the different variables between the hypertrophic and the reference station are shown in Fig. 5. Phytoplanktonic variables were most strongly enhanced at the hypertrophic station followed by the variables of bacterial monomer uptake. The strong increase of glucose and acetate uptake may be regarded as a characteristic of hypertrophic waters.
Total bacteria were less enhanced than variables of bacterial growth, indicating relatively stronger grazing under hypertrophic conditions. Variables of enzyme activity were generally less enhanced than those of monomer uptake. However, this does not necessarily mean that the generation of monomers by enzymatic hydrolysis was low. Maximal velocities of enzyme activities $\left(H_{\mathrm{m}}\right)$ showed a surprisingly low increase in hypertrophic waters. Calculated per-cell activities were occasionally even lower than at the reference station, which suggests a monomer-oriented nutrition of bacteria in hypertrophic waters.

Previous investigations of the Schlei by Bauerfeind (1982) also revealed a very strong increase of glucose turnover in the hypertrophic inner part and a relatively low turnover of a Chlorella hydrolysate (needs hydrolysis by extracellular enzymes prior to incorporation). Following a marine eutrophication gradient (not reaching hypertrophic conditions as in our study) during a plankton bloom in the Adriatic Sea, Karner et al. (1992) also observed a dramatic increase of chlorophyll followed by the variables of bacterial growth and $\alpha$-glucosidase activity. Leucine-aminopeptidase was enormously enhanced, but this may be regarded as a spring bloom effect, which was also observed in the Schlei fjord during the first year of observation (Fig. 2f).

\section{Different patterns of community and cell-specific activities in gradients of eutrophication}

Maximal velocities of hydrolysis as well as hydrolysis rates of the total bacterial communities at the 3 stations showed clearly different patterns over the seasons (Figs. 2 \& 3). This was not the case for respective patterns of activities per bacterial cell. During most sampling periods values of per-cell activity obtained from the 3 stations coincided or overlapped (Fig. 4). A few extraordinarily high measurements of $H_{\mathrm{m}}$ and $H_{\mathrm{r}}$ in the less eutrophic Stns 7 and 8 may be attributed to singular events of nutrient input into normally substrate-limited environments (Giesenhagen 1995). If these were excluded from the correlation matrix annual patterns of enzyme activities per bacterial cell at the hypertrophic Stn 1 and the mesotrophic reference Stn 8 were not significantly different according to Mann-Whitney and Wilcox tests (in 44 out of 48 cases at the $95 \%$ confidence level).

Similar observations concerning the different responses of total and individual bacterial enzyme activities were also made in the eutrophication gradient in the lagoon of Aveiro (Portugal) (Hoppe et al. 1996). Our values confirm in principle patterns of annual distributions of specific activities per bacterial biomass (for chitinase and $\alpha$ - and $\beta$-glucosidase) obtained by 
Vrba et al. (1992) from a eutrophic freshwater reservoir. Güde (1978) observed in C-limited chemostat cultures constant specific enzyme activities (of pectate lyase by Cytophaga) over wide ranges of substrate supply. Addition of glucose as a readily utilisable substrate decreased specific enzyme activities. A clear inverse correlation between individual $\beta$-glucosidase activity and utilisable carbon as well as bacterial growth yield was shown by Middelboe \& Sondergaard (1993).

The values of cell-specific activities depend of course on the number of active bacteria for a given substrate. The ratio between numbers of active bacteria and total numbers of bacteria in hypertrophic waters can vary over a wide range (Sommaruga \& Conde 1997); however, it is not necessarily higher than in less eutrophic waters. During winter the percentage of active bacteria can be lower in less eutrophic waters (Hoppe 1977), but this would result-on the basis of our datain even higher cell-specific activities at our reference station

\section{Different contributions of size classes to total enzyme activity in eutrophication gradients}

Patterns of activity of the measured enzymes were different for the different particle size classes (Table 2). Percentages of enzyme activities $\left(H_{\mathrm{m}}\right)$ in the $>3 \mu \mathrm{m}$ fraction were generally higher during the growth season than during the cold season, especially for chitinase activity and chitin turnover (not shown). Substrates for bacterial chitinases as they are provided by small crustaceans and their larvae are a priori particulate. Crustaceans themselves could contribute to chitinase activity by their molting activity (Vrba et al. 1997). This could be a significant factor in the Schlei, because its microzooplankton biomass can surpass bacterial biomass by up to 60 times (Gast 1985), $\alpha$-and $\beta$-glucosides are constituents of originally particulate compounds and were thus also preferentially hydrolysed by attached bacteria. Tracing the seasonality of enzyme activities in a eutrophic water reservoir, Vrba (1992) also found a predominance of particle (2.5 to $100 \mu \mathrm{m})$ associated chitinase (up to $60 \%$ of total activity) in late summer. Free chitinases $(<0.23 \mu \mathrm{m}$ ) dominated (up to $50 \%$ of total) in late spring. Particle associated $\alpha$ glucosidases (up to $60 \%$ of total) were dominant throughout the year (no measurements in winter), while $\beta$-glucosidase showed a very irregular pattern of distribution.

Activities of free dissolved enzymes recorded in the $<0.2 \mu \mathrm{m}$ fraction were generally enhanced during the cold season, when organic substrates were depleted (Table 2). This finding supports experimental results of
Albertson et al. (1990), who observed enhanced excretion of extracellular enzymes into the surrounding water during the initial phase of bacterial starvation.

Regardless of the season, protease activity was always strongest in the bacterial fraction $(>0.2$ to $<3 \mu \mathrm{m})$. Münster $(1992 \mathrm{a}$, b) also reported a predominance of free bacterial peptidase activity of 45 to $70 \%$ of total activity for the epilimnion of some polyhumic lakes. Proteins are originally particulate photosynthesised organic matter. However, it has been demonstrated that they are degraded by 2 types of hydrolytic reactions (verified for Synechococcus sp. by Martinez \& Azam 1993). Large molecules are hydrolysed at the bacterial cell wall by endopeptidases and the resulting peptides are then further hydrolysed by enzymes located in the periplasmic space. This 2 -fold reaction may offer the chance for peptides to escape from their potential consumers into the water phase. This continuous supply to the pool of utilisable peptides in the water can be a reason for the observed predominance of free-living bacteria in peptide hydrolysis and turnover (Table 2).

\section{General conclusion}

Our study of the Schlei fjord revealed that the role of bacterial heterotrophism was less pronounced in its hypertrophic part. Certainly the availability of utilisable organic matter is of interest for the understanding of this phenomenon. In the hypertrophic inner Schlei the exudation of photosynthesised organic matter (as a percentage of the primary production) was lower than at the reference station in the Kiel Bight (Table 1). In absolute values, exudation in the inner Schlei (average $2.751 \mathrm{mg} \mathrm{C} \mathrm{m}^{-3} \mathrm{~h}^{-1}$ ) was higher than at the reference station (average $0.835 \mathrm{mg} \mathrm{C} \mathrm{m} \mathrm{Ch}^{-3}$ ) (absolute values were calculated from the monthly observations, not from the data in Table 1). Compared to bacterial production it turned out that exudation at the reference station could easily supply the $C$ demands of bacteria (0.226 $\mathrm{mg} \mathrm{C} \mathrm{m} \mathrm{C}^{-3} \mathrm{~h}^{-1}$ for growth plus about the same amount for respiration), while there remained a deficit in the hypertrophic inner Schlei $\left(3.53 \mathrm{mg} \mathrm{C} \mathrm{m}^{-3} \mathrm{~h}^{-1}\right.$ plus respiration) (bacterial growth was calculated by using averages of thymidine uptake and mean cell volume from Table 1 and the conversion factors mentioned in 'Methods').

This deficit in bacterial $C$ demand could possibly be covered by bacterial enzymatic hydrolysis of particles and macromolecular dissolved organic matter. Observed relatively low hydrolysis rates in the inner Schlei in comparison to monomer turnover rates (Fig. 5) do not necessarily mean that the absolute amounts of hydrolysis products were low, because this production 
depends on the pool size of the polymer in question, which is not known. Therefore we tried an expansive approach, where the measured peptide hydrolysis rates, which represent the most important enzymes, were applied to primary production, the potentially total substrate pool for hydrolysis. The calculations revealed that at the reference station an average of $0.19 \mathrm{mg} \mathrm{C} \mathrm{m} \mathrm{m}^{-3} \mathrm{~h}^{-1}$ could potentially be generated by hydrolysis, which is only a minor part of the bacterial $C$ demand. In the hypertrophic inner Schlei, potentially $17.5 \mathrm{mg} \mathrm{C} \mathrm{m} \mathrm{C}^{-3} \mathrm{~h}^{-1}$ could be generated, which is much more than the actual $\mathrm{C}$ demand of bacteria. Thus, bacterial production in hypertrophic waters could be higher than actually measured. If this was not observed, there may be 2 main reasons: (1) exudation of organic matter by light-limited photosynthetic plankton is relatively lower than that of nutrient-limited plankton and (2) inputs of utilisable organic materials by bacterial substrate hydrolysis are significant, but nevertheless restricted to the hydrolysis of non-living POM, which is relatively low in light-limited hypertrophic waters. As a consequence of this, most of the polymeric (particulate) organic matter in shallow hypertrophic waters enters the sediment, which is documented by the accumulation of a thick mud layer over the years.

Similar conclusions about the effect of eutrophication on bacterial growth and extracellular enzyme activities were drawn by Chróst \& Rai (1993), derived from mesocosm experiments in a lake. Phytoplankton exudation of organic carbon covered between 94 and $100 \%$ of bacterial carbon demands under ultraoligotrophic and oligotrophic conditions. In mesotrophic and eutrophic conditions exudates covered only 21 to $34 \%$ of the bacterial carbon demand. The conclusion was that bacteria were organic substrate limited under eutrophic conditions and that they activated their extracellular hydrolytic properties to supply their additional $\mathrm{C}$ demand. We derive from our fjord study that enzymatic substrate hydrolysis in hypertrophic waters certainly contributed to bacterial nutrition but it was not strong enough (due to substrate qualities) to establish a similar relationship between bacterial production and primary production to the one observed in oligotrophic waters.

Acknowledgements. We thank Captain Ohl and the crew of RV 'Littorina' for their help and their courage in entering the extremely shallow fjord with their ship. We greatly appreciate the assistance and help of Regine Koppe, Maren Mehrens, Regine Wicher and Hans Sell.

\section{LITERATURE CITED}

Albertson NN, Nyström T, KJelleberg S (1990) Exoprotease activity of two marine bacteria during starvation. Appl Environ Microbiol 56:218-223
Bauerfend S (1982) Versuche zum Abbau von Plankton- und Detritusmaterial durch natürliche Bakterienpopulationen der Schlei und der Ostsee. Dissertation, Univ Kiel

Bird DF, Kalff J (1984) Empirical relationships between bacterial abundance and chlorophyll concentration in fresh and marine waters. J Fish Aquat Sci 41:1015-1023

Boon PI (1990) Organic matter degradation and nutrient regeneration in Australian freshwaters. II. Spatial and temporal variation, and relation with environmental conditions. Arch Hydrobiol 117:405-436

Chróst RJ, Rai H (1993) Ectoenzyme activity and bacterial secondary production in nutrient-impoverished and nutrient-enriched freshwater mesocosms. Microb Ecol 25: $131-150$

Fuhrman JA, Azam F (1982) Thymidine incorporation as a measure of heterotrophic bacterioplankton production in marine surface waters: evaluation and field results. Mar Biol 66:109-120

Gast V (1985) Bacteria as a food source for microzooplankton in the Schlei Fjord and the Baltic Sea with special reference to ciliates. Mar Ecol Prog Ser 22:107-120

Giesenhagen H (1995) Bakterielle Aktivität im Pelagial der Kieler Bucht (Westliche Ostsee): ein Vergleich zwischen Deckschicht und bodennahem Wasser. Dissertation, Univ Kiel

Gocke K (1977) Comparison of methods for determining the turnover times of dissolved organic compounds. Mar Biol 42:131-141

Gocke $K$, Rheinheimer G (1991) Influence of eutrophication on bacteria in two fjords of the Western Baltic. Int Rev Ges Hydrobiol 76:371-385

Gocke K, Rheinheimer G (1995) Phytoplanktonexsudation. und bakterielle Sekundärproduktion: ein Vergleich zwischen der hypertrophen Schlei und der mesotrophen Kieler Bucht. Bodden 2:189-204

Grasshoff K, Ehrhardt M, Kremling K (1983) Methods of seawater analysis. Verlag Chemie, Weinheim

Güde H (1978) Model experiments on regulation of bacterial polysaccharide degradation in lakes. Arch Hydrobiol/ Suppl 55:157-185

Hobbie JE, Daley R, Jasper S (1977) Use of Nuclepore filters for counting bacteria by fluorescence microscopy. Appl Environ Microbiol 33:1225-1228

Hoppe HG (1977) Analysis of actively metabolising bacterial populations with the autoradiographic method. In: Rheinheimer G (ed) Microbial ecology of a brackish water environment. Springer Verlag, Berlin, p 179-197

Hoppe HG (1993) Use of fluorogenic model substrates for extracellular enzyme activity (EEA) measurement of bacteria. In: Kemp PF, Sherr BF, Sherr EB, Cole JJ (eds) Handbook of methods in aquatic microbial ecology. Lewis Publ, Boca Raton, p 423-431

Hoppe HG, Gocke K, Alcântara F (1996) Shifts between autotrophic and heterotrophic processes in a tidal lagoon (Ria de Aveiro, Portugal). Arch Hydrobiol Spec Iss Adv Limnol 48:39-52

Hoppe HG, Gocke K, Zamorano D, Zimmermann R (1983) Degradation of macromolecular organic compounds in a tropical lagoon (Cienaga Grande, Colombia) and its ecological significance. Int Rev Ges Hydrobiol 68:811-824

Karner M, Fuks D, Herndl GJ (1992) Bacterial activity along a trophic gradient. Microb Ecol 24:243-257

Lorenzen CJ (1967) Determination of chlorophyll and pheopigments: spectrophotometric equations. Limnol Oceanogr 12:343-346

Martinez J, Azam F (1993) Aminopeptidase activity in marne chroococcoid cyanobacteria. Appl Environ Micro- 
biol 59:3701-3707

Middelboe M, Søndergaard M (1993) Bacterioplankton growth yield: seasonal variations and coupling to substrate liability and $\beta$-glucosidase activity. Appl Environ Microbiol 59:3916-3921

Münster U (1992a) Microbial extracellular enzyme activities and biopolymer processing in two acid polyhumic lakes. Arch Hydrobiol Beih 37:21-32

Münster U (1992b) Microbial extracellular enzyme activities in Humex lake Skjervatjern. Environ Int 18:637-647

Riemann B, Bjørnsen PK, Newell S, Fallon R (1987) Calculation of cell production of coastal bacteria based on measured incorporation of ${ }^{3} \mathrm{H}$-thymidine. Limnol Oceanogr 32 : $471-476$

Rieper $M(1976)$ lnvestigations on the relationships between algal blooms and bacterial populations in the Schlei Fjord (western Baltic Sea). Helgoländer Wiss Meeresunters 28: $1-8$

Schiewer U, Gocke K (1995) Ökologie der Bodden und Förden. In: Rheinheimer $G$ (ed) Meereskunde der Ostsee. Springer Verlag, Berlin, p 216-221

Simon M, Azam F (1989) Protein content and protein synthesis

Editorial responsibility: Frede Thingstad,

Bergen, Norway rates of planktonic bacteria. Mar Ecol Prog Ser 51:201-213

Sommaruga R, Conde D (1997) Seasonal variability of metabolically active bacterioplankton in the euphotic zone of a hypertrophic lake. Aquat Microb Ecol 13:241-248

Somville M (1984) Measurement and study of substrate specificity of exoglucosidase activity in eutrophic water. Appl Environ Microbiol 48:1181-1185

Vrba J (1992) Seasonal extracellular enzyme activities in decomposition of polymeric organic matter in a reservoir. Arch Hydrobiol Beih 37:33-42

Vrba J, Kofronova-Bobkova J, Pernthaler J, Simek K, Macek M, Psenner R (1997) Extracellular, low-affinity $\beta$ - $N$-acetylglucosaminidase linked to the dynamics of diatoms and crustaceans in freshwater systems of different trophic degree. Int Rev Ges Hydrobiol 82:277-286

Vrba J, Nedoma J, Simek K, Seda J (1992) Microbial decomposition of polymer organic matter related to plankton development in a reservoir: activity of $\alpha$-, $\beta$-glucosidase, and $\beta$-N-acetylglucosaminidase and uptake of $\mathrm{N}$-acetylglucosamine. Arch Hydrobiol 126:193-211

ZoBell E (1946) Marine microbiology. Chronica Botanica Co, Waltham, MA

Submitted: July 28, 1997; Accepted: December 11, 1997 Proofs received from author(s): March 20, 1998 